\title{
Perbedaan Kadar Protein Urin Sebelum Dan Sesudah Latihan Fisik Pada Atlet di Pusat Pendidikan dan Latihan Pelajar (PPLP) Provinsi Bengkulu
}

\author{
Nadia Wulan Syapera ${ }^{1}$, Zamharira Muslim², Jon Farizal ${ }^{3}$ \\ ${ }^{123}$ Jurusan Analis Kesehatan, Poltekkes Kemenkes Bengkulu, Indonesia
}

\begin{tabular}{|c|c|}
\hline Article Info & ABSTRACT \\
\hline $\begin{array}{l}\text { Article history: } \\
\text { Received Jan } 12^{\text {th }}, 201 x \\
\text { Revised Mei } 20^{\text {th }}, 201 x \\
\text { Accepted Mei } 26^{\text {th }}, 201 x\end{array}$ & $\begin{array}{l}\text { Heavy physical exercise intensity resulted in the cells of the skeletal muscles } \\
\text { work harder, and oxygen needed to increase so that the cells undergo skeletal } \\
\text { muscle vasodilation. While experiencing vasoconstriction in renal blood flow } \\
\text { is reduced to } 20 \% \text { so that it can lead to urinary protein excretion }>1.5 \mathrm{mg} / \\
\text { min. Urine protein is the investigation of kidney function. Data showed that } \\
70-80 \% \text { of athletes have proteinuria after heavy intensity exercise, either in }\end{array}$ \\
\hline $\begin{array}{l}\text { Keyword: } \\
\text { Athletes } \\
\text { Physical Exercise } \\
\text { Levels of Urinary Protein }\end{array}$ & $\begin{array}{l}\text { contact sports athletes and non-contact. Aim:to determine differences in the } \\
\text { urine protein levels before and after physical exercise. Methods: The study } \\
\text { used are pre experimental with one group pretest posttest design. The sample } \\
\text { consisted of } 31 \text { respondents with a total sampling. Measured levels of urinary } \\
\text { protein, untreated physical exercise and urine protein levels were measured } \\
\text { again with the method of examination of } 6 \% \text { acetic acid. Analysis of data using } \\
\text { the Wilcoxon test. Results:there is an increased urinary protein levels with a } \\
\text { mean value of } 0.03 \text { before physical exercise and a mean value of } 0.19 \text { after } \\
\text { physical exercise, but there is no significant difference urine protein levels } \\
\text { before and after physical exercise with } P=0.059 \text {. Conclusions: There are } \\
\text { significant differences in the urine protein levels before and after physical } \\
\text { exercise. }\end{array}$ \\
\hline
\end{tabular}

\begin{abstract}
ABSTRAK
Latihan fisik dengan intensitas berat mengakibatkan sel-sel otot rangka bekerja lebih giat, dan oksigen yang dibutuhkan sel semakin meningkat sehingga otot rangka mengalami vasodilatasi. Sedangkan di ginjal mengalami vasokontriksi, aliran darah berkurang sampai $20 \%$ sehingga dapat menyebabkan ekskresi protein $>1,5 \mathrm{mg} / \mathrm{min}$. protein urin adalah pemeriksaan penunjang fungsi ginjal. Data menunjukkan bahwa $70-80 \%$ atlet mengalami proteinuria setelah olahraga intensitas berat, baik pada atlet olahraga kontak maupun non-kontak. Tujuan: untuk mengetahui perbedaan kadar protein urin sebelum dan sesudah latihan fisik. Metode: Penelitian yang digunakan adalah pra eksperimen dengan rancangan one group pretest postest. Sampel terdiri dari 31 responden dengan metode total sampling. Dilakukan pengukuran kadar protein urin, diberi perlakuan latihan fisik dan diukur kembali kadar protein urinnya dengan metode pemeriksaan asam asetat $6 \%$. Analisis data menggunakan uji Wilcoxon. Hasil: terdapat peningkatan kadar protein urin dengan nilai rerata sebelum latihan fisik sebesar 0,03 dan nilai rerata sesudah latihan fisik 0,19 , namun tidak terdapat perbedaan yang signifikan kadar protein urin sebelum dan sesudah latihan fisik dengan $\mathrm{P}=0,059$. Kesimpulan: Tidak Terdapat perbedaan yang signifikan kadar protein urin sebelum dan sesudah latihan fisik.
\end{abstract}

Kata Kunci : Atlet, Latihan Fisik, Kadar Protein Urin

Copyright C Jurnal Analis Medika Biosains (JAMBS)

\section{Pendahuluan}

Atlet menurut KBBI adalah olahragawan, terutama yang mengikuti pertandingan atau perlombaan (kekuatan, ketangkasan, dan ketepatan). Atlet adalah orang yang selalu melakukan latihan fisik setiap harinya. 
Latihan fisik sudah menjadi rutinitas bagi mereka sebagai persiapan pertandingan, dan untuk meningkatkan daya tahan tubuh terhadap penyakit infeksi (Limuria and Doda, 2016).

Latihan fisik dengan intensitas berat mengakibatkan perubahan fisiologis hampir seluruh sistem tubuh. Saat itu sel-sel otot rangka bekerja lebih giat, dan oksigen yang dibutuhkan sel semakin meningkat sehingga otot rangka mengalami vasodilatasi. Sedangkan di ginjal mengalami vasokontriksi, aliran darah berkurang sampai $20 \%$ sehingga dapat menyebabkan ekskresi protein $>1,5 \mathrm{mg} / \mathrm{min}$. Gromerular Filtsration Rate (GFR) juga menurun, namun tidak sebesar penurunan aliran darah ginjal. Penurunan aliran darah glomerolus akan meningkatkan difusi protein ke dalam tubulus. Penelitian-penelitian terdahulu menyatakan bahwa $70-80 \%$ atlet mengalami proteinuria setelah olahraga intensitas berat, baik pada atlet olahraga kontak maupun non-kontak (Bahori \& Theodorus, 2014).

Pemeriksaan protein dalam urin merupakan pemeriksaan paling sederhana yang dapat memberikan indikasi gangguan fungsi ginjal atau nefritis, Selain itu, atlet yang mengalami proteinuria dapat mengakibatkan edema. Hal ini dapat terjadi karena dapat menurunkan tekanan onkotik plasma (Kohanpour, 2012). Namun perlu dilakukan pemeriksaan penunjang diantaranya adalah pemeriksaan kadar kreatinin, kadar BUN (Blood Urea Nitro-gen), tes protein urin, tes clearance kreatinin, dan sedimen urin (Verdiansah, 2016).

Pusat Pendidikan dan Latihan Pelajar (PPLP) merupakan tempat pembinaan prestasi olahraga dan mempunyai posisi strategis dalam meningkatkan prestasi olahraga di Indonesia pada usia potensial. PPLP Provinsi Bengkulu terdiri dari angkat besi, tinju, gulat, atletik, dan karate. Selain itu, PPLP menerapkan pola makan, dan durasi latihan fisik yang homogen.

\section{Metode Penelitian}

Penelitian ini merupakan penelitian menggunakan penelitian pra eksperimen dengan rancangan one group pre test-post test dan pemberian intervensi latihan fisik dengan durasi 1 jam. Populasi penelitian ini adalah atlet di Pusat Pendidikan dan Latihan Pelajar (PPLP) Provinsi Bengkulu sebanyak 31 orang dan sampel dalam penelitian 31 orang dengan teknik pengambilan sampel adalah total sampling. Dalam penelitian ini menggunakan data primer dengan cara melakukan survei langsung ke lokasi PPLP Provinsi Bengkulu di Bumi Ayu. Peneliti akan menentukan responden sesuai kriteria sampel. Kemudian langsung melakukan pengambilan sampel sebelum atlet melakukan latihan fisik, dan kemudian peneliti akan mengambil sampel kembali setelah responden melakukan latihan fisik selama satu jam. Jika responden berhalangan di hari tersebut, maka akan dilakukan pengambilan sampel pada hari selanjutnya. Saat proses pengambilan sampel, peneliti akan meminta bantuan teman yang sudah berkompeten dalam sampling urine. Alat yang di gunakan adalah tabung reaksi, penjepit tabung, rak tabung, korek api, APD tempat untuk menampung, lampu spiritus, tissue, pipet ukur Bahan yang digunakan pada penelitian ini adalah urine atlet di Pusat Pendidikan dan Latihan Pelajar (PPLP) Provinsi Bengkulu dan asam asetat 6\% dengan merk BE Reagent. Pengambilan Sampel sebelum latihan fisik dan setelah latihan fisik, tampung urine midstream di tempat yang telah disediakan. Analisis data yang dilakukan dalam penelitian ini adalah analisis univariat dan analisis bivariat. Analisis univariat mendeskripsikan karakteristik setiap variabel penelitian dan menghasilkan distribusi frekuensi Analisis univariat mendeskripsikan karakteristik setiap variabel penelitian dan menghasilkan distribusi frekuensi, dan 
anlisis bivariate menggunakan uji $\mathrm{T}$ Dependent berpasangan. Jika distribusi data tidak normal, maka menggunakan uji nonparametrik dengan wilcoxon Sign Rank Test. Data disajikan dalam bentuk tabel.

\section{Hasil Penelitian dan Pembahasan}

Tabel 1 Distribusi Frekuensi Kadar Protein Urin Sebelum Dan Sesudah Latihan Fisik Pada Atlet Di PPLP Provinsi Bengkulu

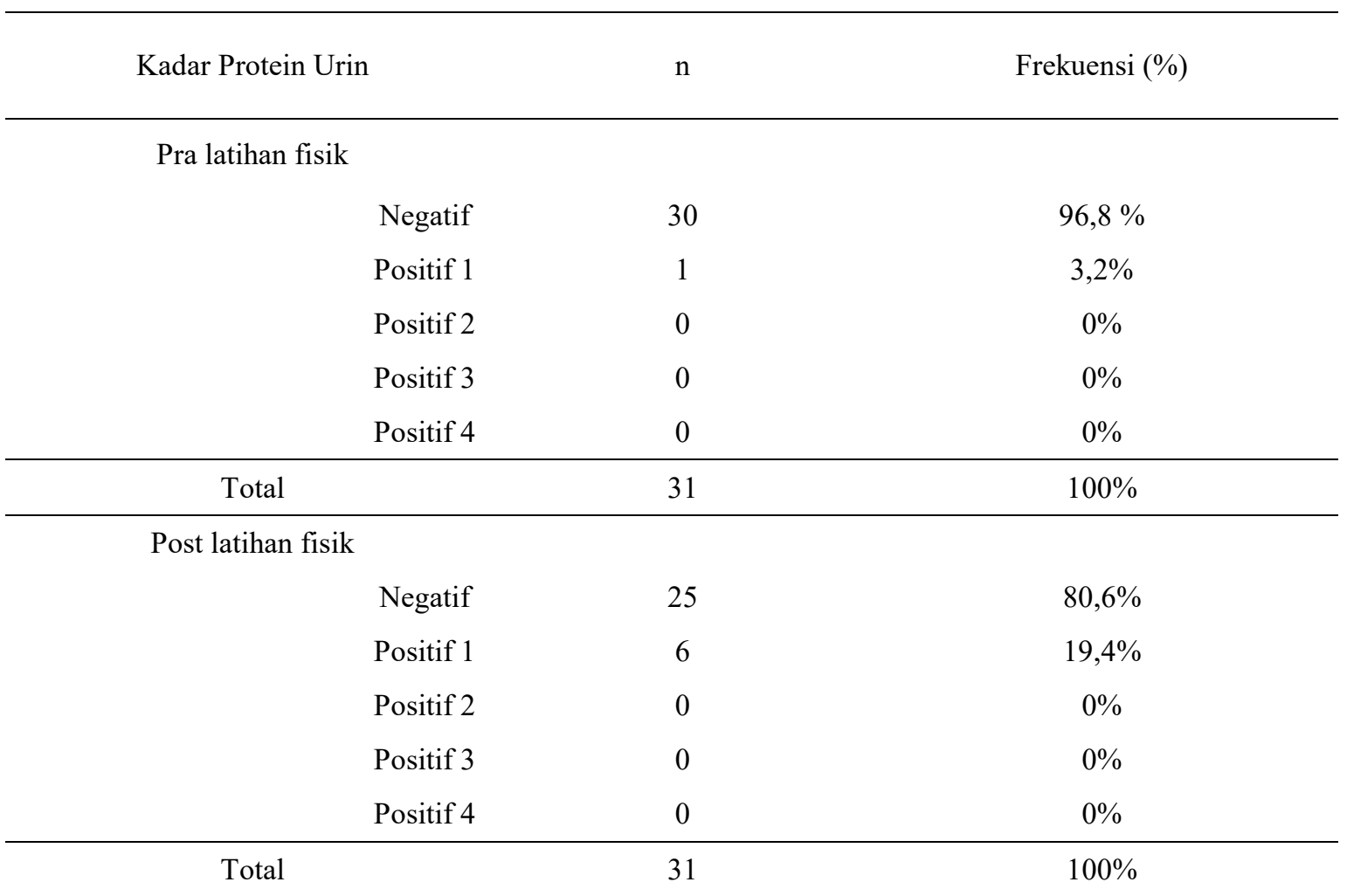

Tabel 1 diketahui hampir seluruh atlet PPLP kadar protein urin urin sebelum latihan fisik negatif (96,8\%) dan sebagian kecil atlet PPLP kadar protein urin sebelum latihan fisik positif 1 (3,2\%). Sedangkan hampir seluruh atlet PPLP kadar protein urin sesudah latihan fisik negatif (80,6\%) dan sebagian kecil atlet PPLP kadar protein urin sesudah latihan fisik positif $1(19,4 \%)$.

Tabel 2 Hasil Analisis Perbedaan Kadar Protein Urin Sebelum Dan Sesudah Latihan Fisik Pada Atlet di PPLP Provinsi Bengkulu

\begin{tabular}{ccccc}
\hline Variabel & $\mathrm{n}$ & $\begin{array}{c}\text { Median } \\
\text { (minimum-maksimum) }\end{array}$ & Mean \pm SD & $\begin{array}{c}\text { P } \\
\text { Value }\end{array}$ \\
\hline Pra latihan fisik & 31 & $0,00(0-1)$ & $0,03 \pm 0,180$ & 0,059 \\
Post latihan fisik & 31 & $0,00(0-1)$ & $0,19 \pm 0,402$ & \\
\hline
\end{tabular}

Journal homepage: http://jambs.poltekkes-mataram.ac.id/index.php/home/index 
Tabel 2 diketahui $\mathrm{P}=0,059$, maka tidak ada perbedaan yang signifikan kadar protein urin sebelum dan sesudah latihan fisik pada atlet di PPLP Provisi Bengkulu.

Hasil penelitiaan ini ada 1 orang positif urin sebelum latihan fisik dan 6 orang posititf urin setelah latihan fisik. Setelah dianalisis dengan perhitungan teknik statistik didapatkan rata-rata kadar protein urin sebelum melakukan latihan fisik adalah 0,03, sedangkan rata-rata kadar protein urin sesudah melakukan latihan fisik adalah 0,19. Hal ini menunjukkan tidak adanya perbedaan yang signifikan antara kadar protein urin sebelum dan sesudah latihan fisik. Sampel yang digunakan adalah urin sewaktu yang dikeluarkan pada satu waktu yang tidak ditentukan.

Atlet merupakan orang yang melakukan latihan fisik di atas orang normal. Saat melakukan latihan fisik, atlet banyak membutuhkan energi sehingga banyak memecah lemak dan protein di dalam tubuh. Sisa-sisa pemecahan protein yang tidak terpakai juga lebih banyak dan akan dikeluarkan dari tubuh melalui urin sehingga terjadi proteinuria.

Proteinuria ditandai dengan adanya kekeruhan pada urin. Potein urin terbentuk saat filtrasi glomerulus mengalami kebocoran, maka molekul protein akan terbuang dalam urin sehingga menyebabkan proteinuria. Ketika membrane glomerulus rusak, filtrasi selektif terhambat dan terjadi peningkatan jumlah protein serum, akhirnya sel darah merah dan sel darah putih menembus membran tersebut dan dieksresikan ke dalam urin (Strasinger \& Di Lorenzo, 2017).

Hasil penelitiaan ini ada 1 responden yang positif protein urin sebelum melakukan latihan fisik, dan setelah latihan fisik protein urinnya menjadi negatif. Protein urin positif sebelum latihan fisik bisa terjadi oleh beberapa faktor diantaranya hipertensi, riwayat penyakit ginjal, dan makanan dan minuman yang dikonsumsi oleh responden karena populasi penelitiaan ini sedikit sehingga tidak ada kriteria sampel. Konsentrasi protein urin berkurang setelah latihan fisik bisa disebabkan oleh urin yang terlalu encer karena disebabkan oleh konsumsi air yang banyak sebelum melakukan penelitiaan. Hal ini bisa menjadikan kadar protein urin berkurang yang dapat menyebabkan tekanan koloid protein menurun sehingga tekanan filtrasi kurang efektif. Minum air yang banyak dilakukan oleh beberapa pasien yang mengalami kesulitan buang air kecil karena dehidrasi setelah mengeluarkan keringat yang banyak. Ini salah satu faktor penganggu dalam penelitiaan ini. (Wahidi and Sopari, 2018).

Keadaan ini sesuai dengan penelitian Zia Hejripour dkk dengan judul Evaluasi Frekuensi Hematuria dan Proteinuria pada Tentara Setelah Aktivitas Fisik, dan Hubungannya dengan Faktor-Faktor Yang Mendasari, dari 110 responden 11 orang tentara (11\%) didapat hasil protein positif sebelum melakukan aktivitas fisik, dan 30 orang tentara $(27,3 \%)$ urin positif setelah aktivitas fisik. Responden memiliki rentang umur $18-25$ tahun (Hejripour, Mohammadshahi and Dormanesh, 2014).

Peningkatan kadar protein urin disebabkan oleh latihan fisik dapat mempengaruhi sistem saraf simpatis yang ada pada tubuh manusia yang menyebabkan permeabilitas dari glomerulus ginjal. Peningkatan kadar protein urin akibat latihan fisik dapat menyebabkan ekskresi protein $>1,5 \mathrm{mg} / \mathrm{min}$. Hal Ini terjadi karena latihan fisik dapat mengakibatkan perubahan fisiologis hampir seluruh sistem tubuh. Saat itu sel-sel otot rangka bekerja lebih giat, dan oksigen yang dibutuhkan sel semakin meningkat sehingga otot rangka mengalami vasodilatasi. Sedangkan di ginjal mengalami vasokontriksi, dan aliran darah berkurang sampai 20\%. Akibatnya aliran darah glomerulus juga menurun tetapi sebesar persentase aliran darah di ginjal. Penurunan 
aliran darah di glomerulus menyebabkan peningkatan difusi protein ke dalam tubulus karena akibat aliran darah yang lambat sehingga darah lebih banyak waktu pada glomerulus (Jumaydha, 2016).

Hasil penelitian ini menunjukkan tidak ada perbedaan kadar protein uri.n yang signifikan antara sebelum latihan fisik dan sesudah latihan fisik. Hal ini sesuai dengan penelitian Kohanpour pada tahun 2011 pada 10 pemain bola dengan perlakuan berlari selama 30 menit dengan intensitas yang berbeda, yaitu $50 \%, 70 \%$, dan $85 \%$. Sebelum dan 20 menit sesudah melakukan latihan fisik, kadar protein urin diperiksa. Pada latihan dengan intensitas $50 \%$ dan $70 \%$ tidak terjadi peningkatan kadar protein urin. Pada latihan dengan intensitas $80 \%$ terjadi peningkatan yang bermakna. Pada tahun 2012, Kohanpour melakukan penelitiaan kembali tentang protein urin pada atlet yang melakukan pertandingan karate. Hasil yang diperoleh bahwa terdapat peningkatan kadar protein urin setelah pertandingan karate, tetapi peningkatan yang terjadi tidak signifikan $(\rho=0,184)$ (Kohanpour et al., 2012).

Menurut Penelitiaan yang dilakukan oleh Forootan pada tahun 2014 yang menjelaskan tidak terdapat peningkatan yang signifikan pada 21 responden aerobik (lompat tali) dengan intensitas $40-70 \%$ maximum hearth rates yang dilakukan secara terus-menerus selama 8 mingggu. Berdasarkan hasil ini juga sesuai dengan penelitiaan dengan judul Gambaran Kadar Protein Dalam Urin Pada Pekerja Bangunan memperoleh hasil responden pekerjaaktivitas fisik intensitas berat didapatkan jumlah responden sebanyk 30 orang yang memenuhi criteria inklusi dan bersedia menjadi responden, dan kemudian dilakukan pengukuran protein dalam urin setelah bekerja. Responden semuanya adalah laki-laki dan memiiki rentang usia 18-51 tahun. Berdasarkan hasil pemeriksaan yang telah dilakukan denga menggunakan nilai rujukan dari Laboratorium Kanaka yaitu $<10$ $\mathrm{mg} / \mathrm{dL}$, didapatkan responden sebanyak satu orang (3,33\%) urin positif (Jumaydha, 2016).

\section{Kesimpulan}

Ada peningkatan rerata kadar protein urin sebelum dan sesudah latihan fisik, dan tidak ada perbedaan yang signifikan kadar protein urin sebelum dan sesudah latihan fisik.

\section{Daftar Pustaka}

Bahori \& Theodorus. (2014). Efek Latihan Fisik Intensitas Sedang Terhadap Kadar Albumin Urin Mahasiswa Akademi Keperawatan Kesdam II Sriwijaya Palembang Tahun 2013, (3), 199-204.

Hejripour, Z., Mohammadshahi, A., \& Dormanesh, B. (2014). Evaluation the frequency of hematuria and proteinuria after physical activities, and its relationship with the underlying factors in selected soldiers. Biomedical and Pharmacology Journal, 7(2), 499-504.

Jumaydha, D. (2016). Gambaran kadar protein dalam urin pada pekerja bangunan. Jurnal E-Biomedik (EBM), 4 (Desember), 5.

Kohanpour, M. A., Vatandoust, M., Mirsepasi, M., \& Nasirzade, A. (2012). Effect of a Karate Competition on Urinary Excretion of Proteins with High. Biological Sciences, 4(6), 660-664.

Limuria, P. Y., \& Doda, V. D. (2016). Pengaruh latihan fisik akut terhadap kadar protein urin pada mahasiswa angkatan 2015 Fakultas Kedokteran Universitas Sam Ratulangi. E-Biomedik, 4.

Strasinger \& Di Lorenzo, M. S. (2017). Urinalisis \& Cairan tubuh. Jakarta: Penerbit Buku Kedokteran EGC.

Verdiansah. (2016). Pemeriksaan Fungsi Ginjal. Cermin Dunia Kedokteran, 43(2), 148-154.

Journal homepage: http://jambs.poltekkes-mataram.ac.id/index.php/home/index 
Wahidi, W., \& Sopari, O. (2018). Konsep Urin Menurut Ibnu Sina: Kajian atas Kitab al-Qanuun fith-Thibb. Jurnal Pendidikan Islam, 4(2), 339. 